
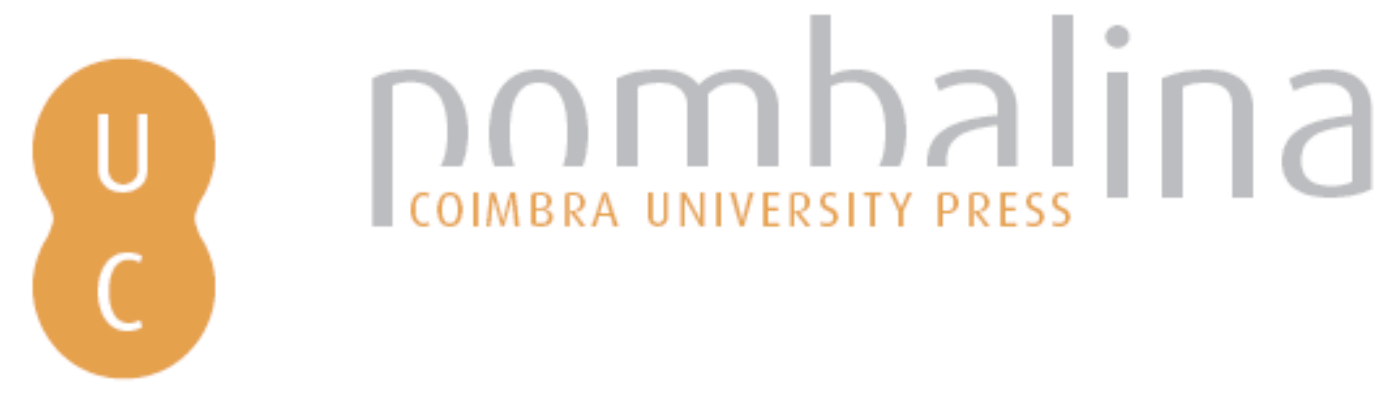

\title{
Burnt area and the wildland-urban interface: a first approach to the Galician wildfires occurred in October 2017
}

Autor(es): $\quad$ García-Martínez, E.; Chas-Amil, M. L.; Touza, J.

Publicado por: Imprensa da Universidade de Coimbra

URL

persistente: URI:http://hdl.handle.net/10316.2/44688

DOI: $\quad$ DOI:https://doi.org/10.14195/978-989-26-16-506_171

Accessed : $\quad$ 26-Apr-2023 04:44:01

A navegação consulta e descarregamento dos títulos inseridos nas Bibliotecas Digitais UC Digitalis, UC Pombalina e UC Impactum, pressupõem a aceitação plena e sem reservas dos Termos e Condições de Uso destas Bibliotecas Digitais, disponíveis em https://digitalis.uc.pt/pt-pt/termos.

Conforme exposto nos referidos Termos e Condições de Uso, o descarregamento de títulos de acesso restrito requer uma licença válida de autorização devendo o utilizador aceder ao(s) documento(s) a partir de um endereço de IP da instituição detentora da supramencionada licença.

Ao utilizador é apenas permitido o descarregamento para uso pessoal, pelo que o emprego do(s) título(s) descarregado(s) para outro fim, designadamente comercial, carece de autorização do respetivo autor ou editor da obra.

Na medida em que todas as obras da UC Digitalis se encontram protegidas pelo Código do Direito de Autor e Direitos Conexos e demais legislação aplicável, toda a cópia, parcial ou total, deste documento, nos casos em que é legalmente admitida, deverá conter ou fazer-se acompanhar por este aviso. 


\section{ADVANCES IN}

\section{FOREST FIRE RESEARCH}

\section{8}

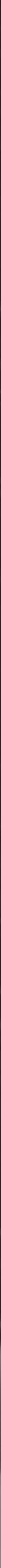


Short contribution - Fire at the Wildland Urban Interface

Burnt area and the wildland-urban interface: A first approach to the Galician wildfires occurred in October 2017

\author{
E. García-Martínez ${ }^{1}$; M.L. Chas-Amil*22 J. Touza ${ }^{3}$ \\ ${ }^{1}$ Universidad de Zaragoza.Pedro Cerbuna 6. Zaragoza, Spain, edgm_73@yahoo.es \\ ${ }^{2}$ Universidade de Santiago de Compostela. Baixada Burgo das Nacións s/n, 15782 Santiago de \\ Compostela, Spain, \{marisa.chas@usc.es*\} \\ ${ }^{3}$ University of York. Heslington, York, YO10 5NG,UK, julia.touza@york.acc.uk
}

Keywords: buildings, Galicia, population, Spain, wildland-urban interface

\title{
1. Introduction
}

Last year catastrophic wildfires in the NW of the Iberian Peninsula destroyed thousands of hectares, provoking human deaths and important economic damages. The wildfire wave occurred in one week in October 2017, with the number of fire incidents reaching peak levels between 14 and 16 October. In those days, the extreme fire meteorology- dry biomass and high temperatures- were combined with storm Ophelia and a high rate of intentional ignitions, which aggravate these conditions. Wildfires occurred in close proximity to residential areas posing an extreme threat to properties and human lives. Forest fire fighters brigades had to prioritize protecting the public for a wide range of emergency situations. This wildfire wave was defined as the worst in history in terms of deaths registered and damages caused in both Portugal and the Spanish region of Galicia. In this paper we characterize the forest fires occurred during this wildfire outbreak of October 2017 in Galicia (Spain). We delimitate the area burnt and describe its spatial characteristics, quantifying the wildland-urban interface (WUI) and population at risk.

The choice of our study area is relevant because the region of Galicia has the highest wildfire incidents in Spain and nearly all fires are human-caused, which traditionally have been associated with illegal behavior through intentional ignited fires (Calviño-Cancela et al. 2016). In 2017, Galicia registered $23 \%$ of the total wildfires burning almost $35 \%$ of the total forest area affected in Spain (MAPAMA 2018), which more than 61,700 ha occurred along the year, mostly during the wildfire wave of October 2017. Our previous study (Chas-Amil et al. 2013) highlighted the vulnerability of the interface to fire in this region. Nearly three quarters of the population settlements are located in the WUI, and that fire ignitions are approximately two times more frequent in WUI than in non-WUI areas. We also found a significant spatial diversity in the vulnerability of WUI areas across this studied region. In this work, we present the first attempt to characterize wildfires occurred in October 2017 in Galicia, focusing on the delimitation of populated areas at risk on WUI areas.

\section{Data and Methods}

We defined the WUI as the area within a 50m radius around buildings at a distance of up to $400 \mathrm{~m}$ from wildland vegetation, where bush clearing is compulsory, according to the current fire-protection legislation in the region (Law 3/2007 of April 9, 2007, addressing the issues of wildfire prevention and suppression, as modified by Law 7/2012 of June 28, 2012 of Galician Forestry). The WUI was obtained combining the most updated layer of buildings from the Galician Topographic Base 1:10,000 (BTG 2016) with information about forest area given by the Fourth National Forest Inventory (IFN4).

The best cloud-free Sentinel 2A-MSI images before and after of the wildfire wave, October 12 and October 27, 2017, were selected and compared in order to determine the severity of wildfires by 
delimitating the area burnt in the studied period. The land use/land cover type (LULC) of the area burnt was determined by using information from the Fourth National Forest Inventory (IFN4). Burned area was also classified attending to their location within or outside the WUI, as well as population and buildings affected. The spatial distribution of the area burnt was also explored by municipalities, describing its spatial characteristics, quantifying the wildland-urban interface (WUI) and population at risk. Jacobs' selectivity index (Jacobs 1974) was used to measure wildfire preference by land cover types and woodland forest type (e.g., Barros and Pereira 2014, Reilly et al. 2018).

\section{Results}

Our results show a total area under WUI in Galicia of 383,711 ha, $13 \%$ of the region. The wildfire wave in October 2017 caused a burned area of 42,314 ha, affecting 97 of 313 Galician municipalities ( $1.43 \%$ of the total Galician area). Forest is the most affected land cover with 40,509 ha, representing $95 \%$ of the total area burned. According to the results from the Jacobs' selectivity index (Figure 1), shrublands was the only land cover burned more than expected based on its presence in the territory, both in the WUI and in no-WUI. These results also show that fires had a clear preference for wood forest lands within the WUI. In terms of population vulnerability to these fires events, results show that a total of 3,665 buildings, corresponding to a total built area of almost 42 ha, 51 population entities and 841 people lived within wildfire perimeters. This shows a high affectation of population and buildings, in fact, we found that 43,048 people live in 500 meters or less to the burned area. The highest relative affectation to the population is detected in forest district XVII-O Condado-A Paradanta, where more than $20 \%$ of the district was burned, and more than $18 \%$ of its population lived within fire perimeters or only $500 \mathrm{~m}$ apart. However, forest district XI-O Ribeiro-Arenteiro was the most affected in terms of burned area $(28 \%)$.
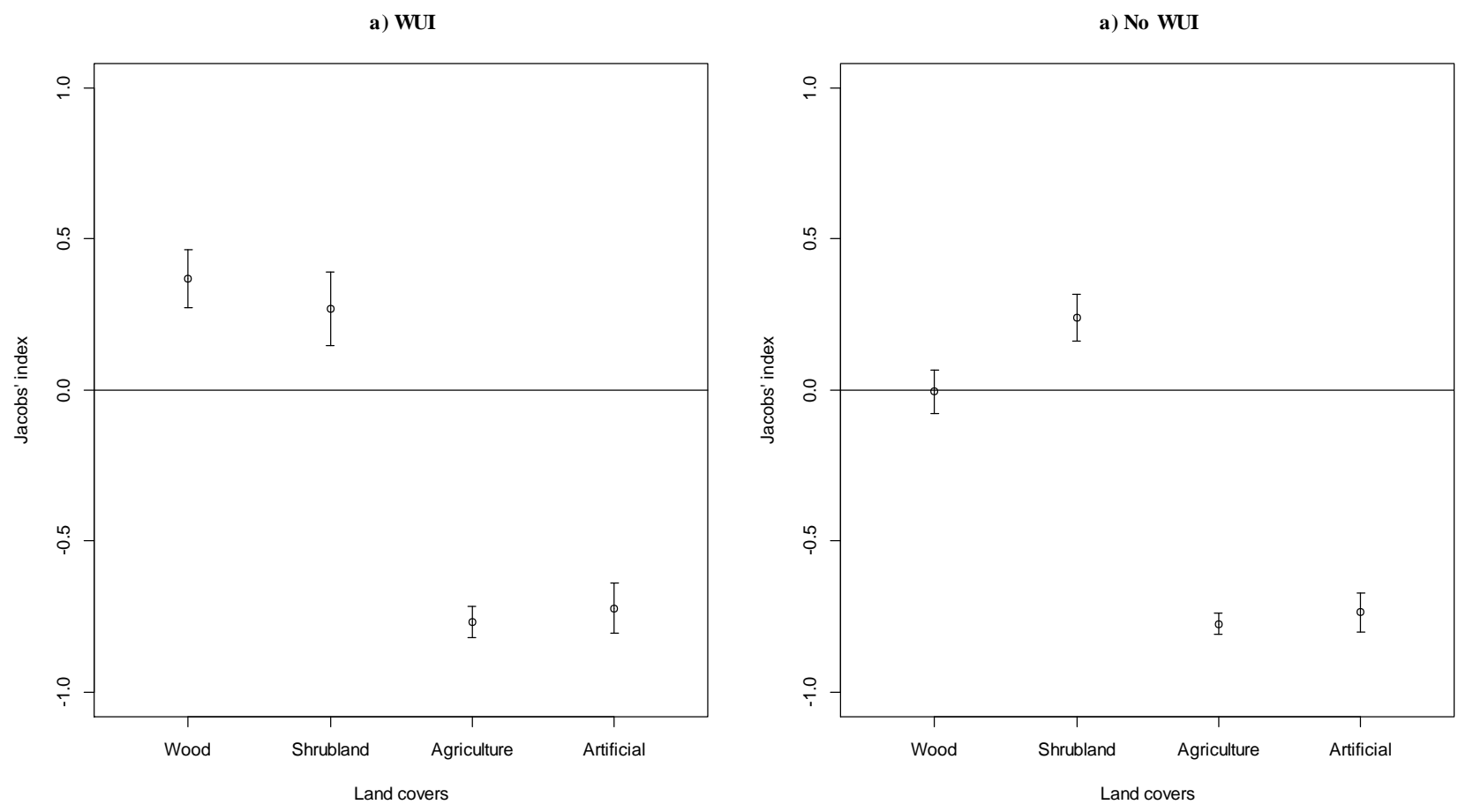

Figure 1 - Mean Jacobs' selection ratios (Ji) with 95\% confidence intervals by land cover types burned in October 2017. 


\section{Conclusions}

This first approach will give us some key element to defend the necessity of implementing an integrated land-use planning, not only based on forest but also focusing on human developments. Our work can lead to the progress of spatial delimitation policies of infrastructures particularly in high risk areas with the aim of developing and promoting plans for the protection of human life, homes and economic activity.

\section{Acknowledgments}

This research was funded in part by Project ECO2017-89274-R MINECO/AEI/FEDER, UE.

\section{References}

Barros, A.M.G., Pereira, J.M.C. 2014. Wildfire Selectivity for Land Cover Type: Does Size Matter? PlosOne, 9(1): 1-10.

Calviño-Cancela, M., Chas-Amil, M.L, García-Martínez, E., Touza, J. 2016. Wildfire risk associated with land cover types, topography and human activities within and outside wildland-urban interfaces. Forest Ecology and Management. 372: 1-9

Chas-Amil, M.L., J. Touza, E. García-Martínez. 2013. Forest fires in the wildland-urban interface: A spatial analysis of forest fragmentation and human impacts. Applied Geography, 43: 127-137.

Jacobs J. 1974. Quantitative measurement of food selection: a modification of the forage ratio and Ivlev's electivity index. Oecologia 14: 413-417.

MAPAMA. 2018. Los incendios forestales en España. 1 enero - 31 diciembre 2017 Avance Informativo Available at http://www.mapama.gob.es/es/desarrollorural/estadisticas/iiff_2017_def_tcm30-446071.pdf [Verified 4 June 2018]

Reilly, M.J., Elia, M., Spies, T.A., Gregory, M.J., Sanesi, G., Lafortezza, R. 2018. Cumulative effects of wildfires on forest dynamics in the eastern Cascade Mountains, USA. Ecological Applications, 28 (2): 291-308. 